\title{
Talking Spaces: Architects and Educators
}

\author{
Noeline Wright ${ }^{1}$ (D) Trent Thompson $^{2} \cdot$ Tim Horne $^{2}$
}

Received: 18 June 2020 / Accepted: 14 October 2020 / Published online: 15 February 2021

(c) New Zealand Association for Research in Education 2021

\begin{abstract}
This article synthesises longitudinal deliberations between two architects and an educator, seeking common ground about learning spaces in schools. As the impetus for new and refurbished school buildings continues in New Zealand, it is timely to unpack instinctual disciplinary practices to better understand space and place in schools. We undertook a process of 'bumping' ideas against one another, establishing intersections around the nature of physical spaces created, inhabited, appropriated and used for educational purposes. The process of documenting our deliberations was dialogic and autoethnographic. Through interrogating ideas about space and place in literature and images, we explored how classrooms function for teaching and learning, and opportunities for both intimate and social learning and teaching. We sought to clarify how architects translate ideas about flexible learning, collaboration and whole class teaching into the design of schools and classrooms. We shared knowledge about pedagogy and architecture, and from these iterative dialogic practices, we offer ideas about educational spaces and places from those positions. As disciplinary professionals, we had internalised so much knowledge and expertise within our own fields, we realised that articulating it to others can be a struggle. We have shared the crafting of this article to partially compensate for misplacing the words to express how and why we do what we do in our own practices. We believe that it matters not only that learning spaces are designed well, but also that architects and educators can talk with rather than past each other.
\end{abstract}

Keywords Learning spaces · Education · Architecture

Noeline Wright

n.wright@waikato.ac.nz

Trent Thompson

trent@moaa.co.nz

http://www.moaa.co.nz/

Tim Horne

tim@moaa.co.nz

http://www.moaa.co.nz/

1 School of Education, University of Waikato, Hamilton, New Zealand

2 MOAA Architects, Ward St, Hamilton, New Zealand 


\section{Introduction}

This article outlines ideas about learning spaces explored through architectural and educational lenses over 18 months, as we explored How do educators and architects talk about space? We are attempting to outline our disciplinary wrestling to make sense of each other's knowing about the design, creation and educational occupation of learning spaces. We first introduce key ideas arising from our interrogation of research literature and architectural artefacts, then explain our research frame before illustrating our deliberations.

\section{Talking About Spaces: Starting Places}

Our discussions highlighted both current challenges architects face while refurbishing, replacing or designing new schools, and raised questions about opportunities educators have to participate in the design discussions about affordances for classroom spaces. Such redesigning or rebuilding creates opportunities for architects to better understand what educators might want or need. On completion, the Ministry of Education undertakes an evaluation to check that the property "is aligned with the school's social and pedagogical dimensions" (Designing quality learning spaces, education.govt.org, 2020, 1 April). So how do social, pedagogical dimensions and spatial output go together?

Wall's (2016) review of the relationship between flexible learning spaces and student outcomes suggested that to maximise the potential of learning spaces, teachers "must be supported to develop their pedagogical repertoire while also being encouraged to explicitly consider the role of the physical environment as part of the planning process" (p. 39). To 'maximise the potential' of new spaces, early consultation during design phases between educators and architects might encourage this process. Maximising the potential is also about fitness for purpose. As Cardellino et al. (2009) argued, in Britain too, "fitness for purpose can only be achieved through more participation of the teachers in the process and the provision of sufficient funds to educate users on how to use the building" (p. 257). This brings us to our question: How do educators and architects talk about space?

Upitis (2004) argued that, "in order for complex systems [like schools] to thrive it is critical that the agents in the system come into contact with one another" (p. 30). She asserts that "it is the job of both architects and educators to come together to determine how the natural and built environments can change in concert with educational philosophy" (2004, pp. 33-34). However, a key 'agent' in the New Zealand educational system (educators) has been broadly excluded when architects and Ministry of Education staff make decisions about spaces for educators and learners.

Our literature review began with Upitis (2004) because broadly, she examined connections between school architecture and complexity theory and whether it helps understand how people interact and move within and between learning spaces. She chose complexity science theory for it explains how "several 'agents' in a system function in some form of self-organization" (p. 27), seeing similarities with school 
operations. She thought schools exhibit similarities with ant and bee colony behaviours, where participants take on specific and often overlapping roles.

Upitis saw classrooms as 'learning collectives' (2004 p. 27). Important to her analysis are aspects such as pattern recognition, 'liberating constraints' (Upitis 2004 , p. 27), diversity in systems and the potential for how learning spaces may exert direct, indirect or decentralised control. 'Decentralised control' in schools, she suggested, may refer to the role a teacher has or exerts in a learning space, or to the influence of the space itself on those within it. Depending on design, school spaces, as both destinations and thoroughfares, invite a myriad of movement patterns of passing through, lingering or dwelling. Architects can, through design and arrangement, influence the shape of a school in relation to its community location. It is these influences that have been under international scrutiny for some time.

The OECD (2013) described distinctions between "stereotyped old-fashioned schooling" (p. 189) and the growing shifts occurring in schools embracing new learning environments. OECD perceived this shift in terms of a balance between social and individual influences, arguing that in newer, more open designed learning spaces, there is greater opportunity for mixing social and individual learning. OECD characterised "stereotyped old-fashioned schooling" as "social with the domination of whole-class teaching and where the notion of personalisation has little place" (p. 189). In other words, learning in such 'old-fashioned' contexts continues as a private endeavour, with little collaboration, sharing or co-operation with other learners. Current views of learning in tandem with disruptions from mobile technologies, have shown that people tend to learn with and from others much more regularly than 'old-fashioned' type schooling tends to permit, both in terms of available physical space and teacher authority and control (Wright 2018). As Deed and Lesko (2015) note, "open learning environments have to accommodate multiple and complex interactions between space and pedagogy" (p. 219). This implies disruption to pedagogical thinking and practices as a consequence of design of the learning spaces.

In contrast, many learning spaces designed within the last decade or so, provide spaces for large groups, small groups, and individual study. Meaning-making can become a more collective affair when spaces offer options. New Aotearoa New Zealand schools tend to open up connections with the wider community through repurposing curriculum and reviewing what counts as authentic learning. Classrooms built within the last decade attempt to orchestrate dynamic spatial arrangements so that students can group and regroup across tasks and learning goals in spaces large enough to make such movement both possible and desirable.

Thus, opportunities for students to traverse individual and social learning contexts occur more easily when spaces accommodate fluidity. Students can be more active players and designers in their trajectory of learning, rather than fixed in spaces that have little room for movement once they are seated. The OECD (2013) for example, argue that learning requires time, involves interplay and interaction, and occurs via a mix of learning approaches, settings and resources within an organic, holistic ecosystem, functioning "over long periods "and in context and includ[ing] the activity and outcomes of learning" (p. 23). This differs from the central locus of control and conformity orientation of "stereotyped old-fashioned schooling" they position as outmoded (OECD 2013, p. 189). Designs that afford opportunities for 
social, collaborative and individual learning, constitute the OECD's (2013) definition of enabling learning environments. The OECD suggest that a learning environment "assumes a social definition of how young people should best learn, in which design, learning leadership and teacher professional leadership play critical roles" (2013, p. 190).

Benade (2019), however, argues that "space will not allow human occupation without also placing its imprint on those same people. Thus, space can both enable and disable; it can facilitate, or hamper, human actions" (p. 54). In other words, spaces might have an effect on whether movement is easy or difficult, and whether learning in different configurations (individual, pair, small group, large group) is hampered or encouraged. These ideas suggest that spaces exert influence on those who are teaching and learning within specific learning environments. Perhaps Benade's view also speaks to educators' burgeoning attention on not only the state of their learning spaces, but also what it means to teach in them. This dual focus was not particularly visible in New Zealand education circles a decade ago.

Alterator and Deed (2018) for example, note that architectural expressions of 'school' have become a focus of attention. They argue that architectural designs for new schools may speak to the policy directions of governments, in turn influenced by best evidence syntheses, such as those emanating from the OECD. Alterator and Deed suggest that through the architectural expression of school buildings, governments might express "educational ideas and aspirations while also offering provocations and prompts to assist in embedding system imperatives. In many ways, the physical facility is a symbol of this shift and is at once behind and ahead of time" (p. 15). Their work has echoes in Wood's (2019) examination of 'built policy' (p. 2), which he suggests encompasses urban planning, design and spatial organisation, creating "special kinds of material and semiotic object[s] ... [operating as] forms of collective meaning-making and control" (p. 2).

Given the interest that school spaces and places have engendered, it follows that having good designs for learning spaces matters a great deal. It also matters that architects have a working understanding of what teachers do in order to undertake the architectural expression of ideas and aspirations and turn them into buildings. It matters too, that architects understand what words like 'collaboration' mean for educators. Tasks involving collaborative or other types of learning, reflect teachers' core pedagogical practices, particularly as they take ownership of what happens in wider and larger learning spaces. It therefore matters that educators can explain concepts about learning to architects. Concepts like 'collaboration' can then be better understood in a design sense.

Of course, if educators have only ever known teaching and learning in "stereotyped old-fashioned schooling" (OECD 2013, p. 189) contexts, explaining possibilities for collaborative and student-centred activities may be challenging to articulate. For example, schools with long traditions of teacher-centric classroom practices may have difficulty in understanding the pedagogical opportunities bigger, more open spaces might offer, resisting the potential of such spaces if different modes of pedagogical practice are not already practised. Thus, discussing ideas with architects about concepts like collaborative learning or team teaching through design stages may be problematic. This disruptive change context may 
account for the attention teachers now apply to the nature of teaching spaces. New types of learning spaces appear to destabilise some teachers' pedagogical practices and beliefs, and their role in classrooms. While new school staff have relished opportunities to reform the shape and practices of learning, the prospect of rethinking teaching and learning has been difficult for some teachers, students and parents, especially if such newness straddles old and new on the same school campus (Park 2015; Wright 2018).

While we acknowledge such disruption has been significant for some schools and teachers, it is not the focus of this article, even though it resonates with the view that spaces and places act as mediating influences on those occupying them. Given the opportunities and tensions that new learning spaces might afford, we wanted to figure out how teachers and architects might talk with each other rather than past each other. If the physicality of space and place exerts mediating effects on what happens in them, how people experience them, became part of the conversation.

Butler and Sinclair (2020) considered the quality of the educational practices taking place inside schools. They argued that schools as places are experienced as meaningful locations for those using them. These experiences invoke aspects of human scale, history, cultural characteristics and markers, often remembered emotionally. This perspective resonates with Agnew's (1987) 'sense of place'. As a term, it has an evocative quality, contributing to how we understand spaces and places, especially those for and about learning. When memories about school are nudged, we may respond emotionally. Butler and Sinclair (2020) suggest that people develop attachment to, and ascribe meaning to, places. Both attachment and ascribed meaning can vary according to "cultural background and positionality; in fact, every person has a unique sense of place" (Butler and Sinclair 2020, p. 67).

The concept of a "unique sense of place" in relation to schools may therefore help explain why teachers have become interested in thinking about possible effects learning spaces might exert on the learning occurring within them. As educators progressively confront new learning typologies, they may re-examine ideas about not only conducting and organising learning in the new spaces, but also rethinking what a learning space or place might be or mean.

The role of the architect in designing appropriate classrooms has therefore become significant. De Carlo (1969), in exploring the function and purpose of schools, argued that "collective participation in the formation of the environment [of a school] implies radical changes in the role of the architect" (p. 22). Our 'bumping' is helping us better understand interrelations that might lead to greater collective knowledge about educational spaces and their functions.

Patterns of movement, relationships between spaces and educational practices and mediating effects are ideas explored in the literature (Butler and Sinclair 2020; Uline and Roberts 2009; Upitis 2004). Uline and Roberts for example, suggest that learning environments are 'mediating conditions in which teaching and learning takes place' (p. 378). This idea implies that facilities may affect students' outcomes, perhaps in ways that connect with movement as well as being in one place. As spaces and places in schools are devised to pause, move and provide collaborative opportunity or mass instruction, then common understanding of pedagogical requirements become important factors in school designs. 'Dwelling' for periods of 
time affords the potential inheritance of a meaningful location, linked by emotional connections during acts of teaching and learning, and a school's rituals and routines.

While spaces mediate activities within them, they can also be sites of comfort (Rybczynski 1987), rest, occupation, or appropriation. The latter two are addressed more specifically later. Ralph and Levinson (2019) traced ideas of occupation and appropriation, through ways disaffected young people used various spaces in a British secondary school. Their findings suggest that "spaces [in schools] created for explicit purposes amass extra, unintended, functions once they are occupied and experienced" (p. 1189). Thus, while spaces may mediate and/or imply what should happen inside them, those inhabiting the spaces can potentially dispute or alter (for better or worse) the expected use of a space or place.

Such ideas initiated our discussions and pondered a number of questions about space, occupation, appropriation and mediation. For example, what do architects need to understand about learning when they design learning spaces? And how can educators contribute ideas and engage in meaningful discussion with architects about the shapes, patterns, joys and challenges of learning? Our ideas are represented and synthesised in three topics within "Our collective thinking" sect., which follows a brief summary of how we documented, framed and analysed our discussions and sources.

\section{A Research Frame}

Over an 18 month period, we met to talk about our respective interests in the design and use of educational spaces and places. On one occasion, the three of visited a school the architects had been involved in designing, as a rebuilt school. The visit occurred as part of an event for architects. This primary school visit became the catalyst for our discussions. The architects were also involved in modifying the interior design of a local school that the educator also knew. Some later discussions occurred when we discussed the same school's existing building plan to explore ideas about what their design modifications were tasked to achieve. These occasions helped strengthen our search for common ground, and made clearer the issues the building created for teachers and learners, and the challenges of design improvements. During the Covid-19 lockdown period in New Zealand, we met twice weekly via Zoom, sharing screens to brainstorm interpretations of images and sketches of schools and spaces. Some images led to intense debate about collaboration. In turn, this provoked discussion about learning theory and practice, as well as ways architects might interpret concepts like collaboration and represent them in floor plans.

Singer and Woolner's (2014) observation about the value of digital technologies to connect people and disciplines is entirely appropriate here. Zoom acted as a mediating 'catalyst' (p. 186), joining us to "explore and exchange ideas, appreciate each other's unique views" and attempt to consider what may be "fundamental conflicts and obstacles in the design of learning environments over the longer term" (Singer and Woolner 2014, p. 190).

In research terms, this has been a dialogic give and take (Bakhtin 1981). In some respects, our process of making sense of difficult ideas when our respective 
disciplinary knowledge is so different, was autoethnographic; in other respects, it was chaotic, circular, head-splitting and time-consuming.

The autoethnographic tilt arises through us attempting to produce a "meaningful, accessible, and evocative" (Ellis et al. 2011, para 3) artefact (this article) that engages with our professional knowledge, representing and respecting each other's perspectives and professional identities. Our efforts to find a common language about educational space and place engaged us in what Ellis et al. (2011) describe as both "insiders (cultural members) and outsiders (cultural strangers)" (para 7). Simultaneously, we occupied both positions as we analysed our experiences and epiphanies of wrestling with concepts of spaces and places. In this process, we have used our "personal experience to illustrate facets of cultural experience" with a view to making those facets familiar to others (Ellis et al. 2011, para 9). In Ellis et al.'s (2011) terms, we have potentially undertaken a 'co-constructive narrative' in which we outline "meanings of relational experiences... particularly how [we] cope with ambiguities, uncertainties, and contradictions" (para 23). As individuals, we are working through ideas to arrive at, across our disciplinary divides, a collective effort.

Wrangling these ideas into a document that expresses coherent thought about ways architects and educators might make sense to each other, was a struggle of translation. As lockdown rules lifted, we met in person, but less frequently. Bakhtin's (1981) ideas about the nature of communication as a two-way process, described both our series of give-and-take, and centred attention on meanings behind words. Thankfully, Bakhtin suggested that there was no need to arrive at definitive answers. While at times we teetered on a precipice of talking past each other, we nonetheless persisted.

The article therefore focuses on illustrative points of connection about contemporary spaces and places designed by architects for teaching and learning. These points are:

- The mediating influence spaces and places may have: to slow us down, offer opportunities for contemplation, or affect what takes place in it

- Creating spaces for various kinds of learning, such as collaborative activities, where learning may be experienced as a shared intimate act

- The propensity for people to colonise or appropriate spaces, potentially changing their original, intended use.

\section{Our Collective Thinking}

This section summarises our collective thinking through our dialogic give-and-take, or, as Upitis (2004) suggests, 'bumping' (p. 28) ideas against each other. We worked our way to points of connection about how architects and educators might understand the constraints and affordances of different types of learning. We begin by focusing on how built spaces might mediate human behaviour, such as influencing us to slow down, pause for thought, dwell, or speed up as indicated earlier. We then focus on how teachers understand and practise collaboration, and how this might 
affect architects' understanding as they design schools. The section concludes by referring to ways people may colonise, appropriate or change spaces.

Figure 1 offers a glimpse into architects' design thinking. The series of abstract visual interpretations of our discussions about movement into and out of spaces, social interaction, as well as dwelling or pausing, indicate an architectural way of thinking. The sketches suggest the visual language architects use to express nascent design options for classrooms and/or corridors. Images in Fig. 1 are alluded to in the next sections, partially expressing Wood's (2019) view that buildings have a "semiotic capacity [acting as] both sites and mediums for discourse" (p. 5).

\section{Spaces and Places as Mediating Influences}

We discussed places and spaces and their effects on people, especially in learning contexts, where patterns of movement go hand-in-hand with constraints and affordances. We discussed 'space' as both an abstract concept, and as physical. This led us to Cresswell's (2004) work on human geography. Cresswell drew on Agnew's (1987) three aspects of place (location, locale and sense of place) that cohere as 'meaningful location'. Location is, in simple terms, a physical space: which a map can indicate. Locale, however, is the "material setting for social relations" (Cresswell 2004, p. 7), and is about a context for meaning-making by those inhabiting and interacting the space/place. Agnew's sense of place, therefore, evokes emotional connections and, possibly, memory, which is drawn on when people recall a place, connections with others, and time. Cresswell argues therefore that "Place, at a basic level, is space invested with meaning..." (p. 12). Butler and Sinclair (2020) similarly argue that places are where we 'learn about ourselves... and connect to our... surroundings" (p. 64). The possibilities regarding ways places and spaces influence us as we use them, linked to our debates about relationships between aesthetics, form and function.

We concluded that 'space' may have more abstract connotations than 'place': space contains both volume and area, while place, according to Cresswell (2004), has "space in between" (p. 8). Cresswell presents 'place' as a pause and 'space' as movement; in other words, spaces are areas we move through in order to arrive at places where we pause, cluster or dwell. If we apply the concept of movement and pause, a school is both a place and a container of spaces while also being a
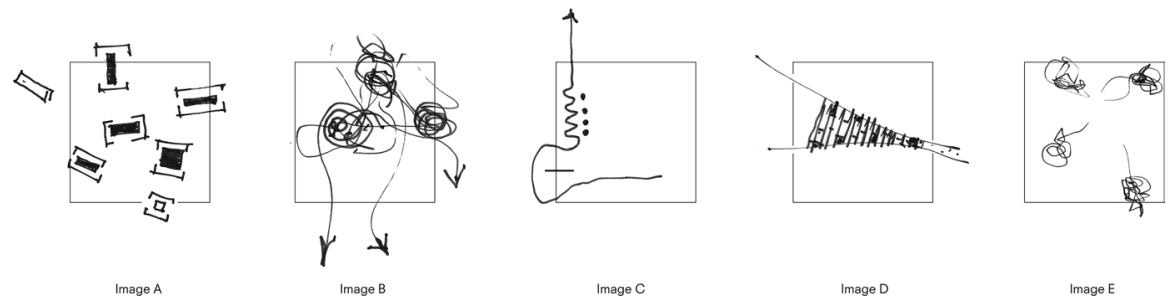

Fig. 1 Movement, dwelling, and social interaction in possible learning spaces: Sketches by MOAA Architects 
location (one of Agnew's trio of location, locale and sense of place). Some spaces are for movement (corridors, gyms, fields, paths), while others are for lingering (classrooms, libraries, staff rooms, social spaces, cafes) (Image C Fig. 1). Spaces may therefore mediate how we might see, know and understand the environment of the school, through connections and attachments between people and places. Such mediation may create occasions for forming long lasting experiences and meaning: some positive, some not.

Since classrooms and other kinds of learning spaces/places can take on personal resonance, they can become associated with evoking memories (Rosén Rasmussen 2012). Perhaps this also occurs when we undertake collaborative tasks. We may experience these tasks and activities as intimate learning acts which become significant when learning is satisfying and achievable. Our feelings of satisfaction and achievement, may then associate a place with the pleasure, evoked long after the physical here-and-now is gone. How well spaces mediate opportunities for intimate learning acts, is likely to relate to both their physical design and intended purpose, as well as the learning educators facilitate within them. It also connects with notions of $d$ welling (addressed later). Beforehand, we illustrate collaboration as both a pedagogical construct, and a design consideration. It is in such cases that messages and meaning between architects and teachers coincide.

\section{Collaboration and Spaces}

Collaboration arose as we examined a range of architectural sketches of classroom/ school floor plans which labelled certain spaces as collaboration, as if its mere mention accounted for intended use. We talked through what educators and learners need if spaces afford collaboration. We discussed the value of more intimate spaces for small group work and problem-solving, because collaboration among learners usually works best in smaller spaces than open, large, undifferentiated rooms. The size of the group undertaking it is also important; being cocooned in small spaces is helpful for shutting out distractions and better promotes dwelling on the problem at hand. Collaboration, we decided, is most likely an intimate learning act afforded by the nature of a space. All of the sketches in Fig. 1 illustrate the potential for a range of activities to occur within the and beyond the outlined spaces.

In a pedagogical sense, collaborative opportunities support student-centred learning and social constructivism. One of the features of future-focused learning is about developing skills that can be applied across disciplines, contexts and problems (Dumont et al. 2012). Learning that focuses on capabilities for an uncertain and possibly unstable future adult life, suggest that.

Co-operative group work, appropriately organised and structured, has demonstrated very clear benefits for achievement as well as for behavioural and affective outcomes. Co-operative methods work for all types of students because, done well, they push learners of all abilities (Dumont et al. 2012, p. 6).

While group work supports developing negotiation skills as well as understanding and appreciating different perspectives, individual learning is also valued. There 
are times when one must think and develop ideas alone. Later, ideas and thoughts can be tested when discussed and shared with peers. For different types of learning opportunities in classrooms, schools need spaces for both intimate and less intimate learning. Students need options for pausing, dwelling and moving to take advantage of different resources, activities, tasks and goals.

Alongside spatial sequences of movement, dwelling and pausing, classroom furniture, whether bespoke, fitted or bought ready-made, becomes an important element to complement learning practices. Starkey et al.'s (2020) article in this issue addresses furniture in a primary school classroom, asserting its influence on decisions that both students and teachers make about how they undertake learning and teaching. For example, whiteboard tables meant that in working together, students could rub out calculations as they concentrated on mathematics tasks, while window seats invited quiet work, reflection or reading. The window seats appeared to be the go-to space when students were tired, grumpy or whakamā (Starkey et al. 2020). These two examples indicate ideas about pausing, dwelling or moving and the value of furniture for different kinds of purposes.

Most newly built New Zealand schools contain at least a few oversize open spaces used for teacher instruction or information transmission for large numbers of students. On such occasions, it is common for one teacher to address the larger group, explaining any tasks, focus, concepts or theory students need before progressing onto smaller group or individual endeavours. Formal instruction usually occurs from the front of a room, resembling traditional teaching where teachers talk and students listen.

Benade (2019) noted that underlying ideas about flexible learning environments suggest they are more likely to "encourage and enable teachers to exchange 'frontof-the-room', single teacher presentational approaches for collaborative, dispersed and facilitative styles, often in teams, working with multiple students in shared, common learning spaces" (p. 53). While this view mirrors ideas about ways of using these kinds of spaces, larger group instruction or meetings are also part of the fabric of school life.

In an architectural sense, 'collaborative, dispersed and facilitative styles' are represented as opportunities within spaces. Figure 1 is a collection of images speaking to interpretations of collaboration, dispersal, intimacy and facilitation.

\section{Colonising/Appropriating Learning Spaces}

'Dwelling' as a concept implies possibilities. These range from occupying/colonising actions, through to more abstract notions of 'thinking about'. This is what dwelling on a thought refers to. We spent time debating 'dwelling' as a concept and its connection with issues of learning and being, and the design of spaces in which these can happen. As Cresswell argued, "Place, at a basic level, is space invested with meaning in the context of power" (2004, p. 12). Well-designed spaces offer opportunities for change: of power dynamics between teachers and students; how a space is used; as well as who uses it or takes it over. This also implies changes to pedagogical modalities. Having available a range of spaces appears to make it easy 
for students to agentically use spaces to suit themselves and express ownership and belonging, especially when students wish to use spaces for special interests or creating connections with others. For example, in Wright and McNae's (2019) project centred on understanding how students and teachers developed a sense of ownership as founding members of a new secondary school, the LGBTQI Club, initiated by students for students, showed how an unoccupied space became an opportunity for these students to "form identities, build relationships, and get support safely together. The initiator noted that it has become 'a space where we can just chill and not be worried about other people", (Wright and McNae 2019 p. 8).

In the case of the LGBTQI club, they found a space to forge identities, pause, dwell and move together (Image C, Fig. 1). Perhaps this example captures the potential for groups to separate off from larger community as represented by the dots beside the squiggle in Image $\mathrm{C}$ (Fig. 1). The dropping out for pause allows small groups to eddy and coalesce, perhaps slowing down for periods of time. For the LGBTQI Club members, they could separate off to build their own group cohesion while developing their individual and collective identities.

Inhabiting a space - marginal or central- contains not only suggestions of making a space one's own, but also relative to others, such as peers and teachers. Making meaning occurs when spaces meet the needs of individuals or social groups as they colonise or appropriate them. Figure 1 offers a range of interpretations for individuals and groups moving into, out of and through learning spaces.

Appropriation is possibly less about claiming territory than using a space differently than it was intended, or using a tool in a way that its creator had not yet thought of. The concept of dwelling invokes thought, physical presence or pause. Spaces (and their contents) may slow us down, inviting contemplation or quietness. Corner beanbags invite pause for thinking, relaxing, snuggling and creative dreaming. In this regard, Butler and Sinclair (2020) observe that places can be contexts in which two influences are at work: human agency and social structures, to which Benade (2019) may add that a classroom space itself can exert influence.

Appropriation is multifaceted. The delineation of space, defined firstly by the architect, is inherited and interpreted by teachers to map pedagogical practice within it. Students then use the space and its resources to undertake their tasks. When they learn within settings that invite decision-making and belonging, it becomes easier for students to appropriate a space's resources. A sensitively designed space will, therefore, invite much more socially inclusive, agentic occupation and appropriation than might otherwise be the case. When such conditions are present, learners are better able to assert themselves as decision-makers and contributors within their school community, while also able to develop their individual identities.

While agentic and inclusive goals feature in some aims of new schools which can create fresh values and goals for learners (Wright 2018; Wright and McNae 2019), Butler and Sinclair (2020) argue that some schools might prevaricate in their goals, vision and mission. Some may prefer to perpetuate more traditional, historical values and beliefs about what they should foster, while others, like many new schools, resist reproducing the status quo (Bourdieu and Passeron 1977). Many newer New Zealand schools focus on preparing students for a much less predictable future and develop values and practices to address that aim. Either way, schools mediate and 
influence the behaviour of its staff and student community, through promoting specific values, routines, rituals and practices. The spaces and places within schools can mediate its values and practices through the affordances of scale, shape and contents. Cresswell (2004) observed that "most places are ... often the product of everyday practices. Places are never finished but produced through the reiteration of practices - the repetition of seemingly mundane activities on a daily basis" (p. 82). Repeated practices build custom, shared belief, and, possibly, safety within school spaces. As such, they become part of the fabric of experience in a place, exerting direct or indirect influence on teachers' abilities to adapt to new learning spaces (Deed and Lesko 2015).

Even as school routines may seem mundane, they serve to keep order, offer predictability and focus, regardless of schools' ethos. The scale of a learning space, its acoustics, ambiance, and contents, together with a teacher's facilitation practices, serve to build either belonging and safety, or tension and stress. These are things teachers exert influence over. For example, lining up outside rooms, using lockers, removing shoes in certain spaces, donning safety gear in other spaces, or sitting at desks: all build predictability and routine. These predictable routines can either feel oppressive or safe, helped or hindered by the building design.

In Blaisdell's (2020) view, place and space are both embodied and geographical. This view resonates with Agnew's (1987) 'sense of place' concept, which helped us understand more about issues of design and occupation. Before teachers take over learning spaces however, architectural design exerts influence over how spaces and places may be understood and used. An architect's role in designing the scale and 'feel' of learning spaces, therefore, is not neutral (Alterator and Deed 2018), and nor is the role of students in occupying learning spaces.

To understand how spaces in secondary schools might be used by disaffected students, Ralph and Levinson (2019) examined their behaviours across various spaces within a British school. In describing how students on the margins made sense of, colonised or appropriated certain spaces, they suggested that place can be understood as involving connections and relationships, and exclusion and inclusion. Students on the margins occupied the edges, creating communities of their own. Within classrooms, disaffected students might gravitate to room's margins (Image E Fig. 1). The 'feel' of learning places is thus an important design focus, leading Ralph and Levinson (2019) to argue that.

Pedagogical practice is, in part, defined by the spaces that enable it to occur, both guiding and constraining it. Educational space itself composes a tacit form of teaching and this visible but obscure aspect of the curriculum is a significant force that gives form to the everyday activities taking place in school (Ralph and Levinson 2019, p. 1194).

Their views offer a window onto some tensions inherent in architects' challenges in creating educational spaces, whether new, replacements or refurbishments. Ralph and Levinson's perspective helped us review how spaces might mediate experience and use. Starkey et al. (2020 in this issue) highlight mediating effects, especially when the furniture within a space invited either specific activities, behaviours, or modes of repose. Learning spaces have complex roles, supporting both the nitty 
gritty of daily teaching and learning, and, in secondary schools, the regular churn of teachers and students, where students and teachers may shift from room to room. The potential for built environments to both influence behaviours and be affected, suggests that designing schools is complex, mirroring some complexities of teaching and learning. School buildings thus act as passive participants across a range of scales.

Simultaneously, they are a specific location, and a marker within a community. They are also buildings that share in neighbourhoods, offering a collection of rooms that contribute to that neighbourhood, and opportunities to inspire conversation. The responsibility is to provide spaces for learning that are welcoming, and adaptable, so that teachers can use them well for learning goals. As architects are aware of these scales, school designs become an expression of their confluence.

\section{Conclusion}

Arising from our discussions, brainstorms and reading, we concluded that the design of learning spaces matters. It matters in terms of scale, purpose, function and form. It also matters that architects have a conceptual understanding of what teachers $d o$ and plan to do in learning spaces, and what students do in these same areas. As Deed and Lesko (2015) noted, new classroom designs disrupt the norms of pedagogical practice. Consequences can be profound. We also decided that a common vocabulary about place, space and scale to avoid talking past each other, mattered. We also agreed that teachers have difficulty understanding what it is that architects need to know, if they are to interpret educational needs into designing spaces and places. There is potential for built structures to have direct, indirect or decentralised control over those who use them (Upitis 2004), which are likely to affect the quality of educational experiences.

The sense of 'place' schools evoke and the extent to which they afford positive learning experiences, matters to all who teach and learn in them. Those 'dwelling' in schools need fit-for-purpose spaces, such as areas facilitating (together and separately) students' and teachers' collaboration, planning and reflections, plus socialising and intense, individual thought, and with or without specialist equipment. The sketches (Fig. 1) representing possible options for the function of learning spaces, offer a glimpse into architects' design thinking. To create new educational areas that combine aesthetically functional and evocative features, architects play with ideas first in such sketches. Understanding how school spaces work, assists this development.

In designing schools, architects are therefore faced with 'liberating constraints' (Upitis 2004, p. 27), including, in the case of new schools, the Ministry of Education's procurement procedures and regulations for school buildings, coupled with the opportunities and limitations of school sites and budget. Architects must use these factors to interpret information about the nature of a school, its learning aims, vision and cultural frame before designing. If architects have a minimal understanding of what it means to teach and learn, it is possible for what they design to be frustrating 
as learning spaces, for teachers must make educational spaces operate meaningfully for learners (Cresswell 2004).

There is also some strangeness in realising, as Cresswell observed, that "the places we have to negotiate are the result of the practices of those who were here before us", implicating the legacy function of educational routines, rituals and values that develop over time. Conversely, a new school is, he argued, a "place in the future [that] will be different" (p. 36), perhaps having greater focus on what Alterator and Deed suggest as "social occupation" (p. 5). New architectural expressions of schools, they argue, potentially assist in symbolising shifts and disruptions in educational ideas and aspirations. This resonates with Deed and Lesko's (2015) suggestion that teachers' activities in open learning spaces is a 'form of systemic adaptation" (p. 220).

In summary, it matters we think, that educators have a seat at the design table if school designs - their scale, form and function - are to liberate rather than constrain what happens inside them. Ideally, educators and architects can talk with each other rather than past each other, so that designs implicate educational aspiration. Teachers being open to rethinking their pedagogical practices to take advantage of the disruptions of new spaces, might result in more satisfying educational experiences. By being able to express these practices and possibilities to architects, architects may in turn, acquire deeper knowledge of what it means to teach and learn, so learning space designs continue to liberate rather than constrain.

\section{References}

Agnew, J. A. (1987). The United States in the world economy. Cambridge: Cambridge University Press.

Alterator, S., \& Deed, C. (2018). School space and its occupation: Conceptualising and evaluating innovative learning environments. Leiden: Brill.

Bakhtin, M.M. (1981) The dialogic imagination: Four essays (Michael Holquist. Trans.). Caryl Emerson and Michael Holquist. University of Texas Press

Benade, L. (2019). Flexible learning spaces: Inclusive by design? New Zealand Journal of Educational Studies, 54, 53-68.

Blaisdell, B. (2020). Right to the classroom: Seeking spatial justice in kindergarten. Urban Review, 52, 151-172. https://doi.org/10.1007/s11256-019-00516-3.

Bourdieu, P., \& Passeron, J. C. (1977). Reproduction in education, society and culture. Thousand Oaks: Sage.

Butler, A., \& Sinclair, K. A. (2020). Place matters: A critical review of place inquiry and spatial methods in education research. Review of Research in Education, 44, 64-96. https://doi.org/10.3102/00917 32X20903303.

Cardellino, P., Leiringer, R., \& Clements-Croome, D. (2009). Exploring the role of design quality in the building schools for the future programme. Architectural Engineering and Design Management, 5, 249-262.

Cresswell, T. (2004). Place: A short introduction. Hoboken: Blackwell.

Deed, C., \& Lesko, T. (2015). 'Unwalling' the classroom: Teacher reaction and adaptation. Learning Environments Research, 18, 217-231.

Designing quality learning spaces, education.govt.org, (2020). https://www.education.govt.nz/school/ property-and-transport/projects-and-design/design/design-standards/designing-quality-learningspaces/.

Dumont, H., Istance, D., \& Benavides, F. (2012). How can the learning sciences inform the design of 21st century learning environments? Practitioner Guide. From, The Nature of Learning: Using research to inspire practice. OECD. Retrieved from https://www.oecd.org/education/ceri/50300814.pdf 
De Carlo, G. (1969). Why/How to build school buildings. Harvard Educational Review, 39(4), 12-35. https://doi.org/10.17763/haer.39.4.r1163153200753u4.

Ellis, C., Adams, T. E., \& Bochner, A. P. (2011). Autoethnography: An overview [40 paragraphs]. Forum Qualitative Sozialforschung/Forum: Qualitative Social Research, 12(1), 273.

OECD. (2013). Innovative learning environments. Educational Research and Innovation, OECD. https:// doi.org/10.1787/9789264203488-en.

Park, M. (2015). The affordances of digital technologies within a Year 9 blended learning programme in a Flexible Learning Space. Unpublished masters dissertation. University of Waikato.

Ralph, T., \& Levinson, M. (2019). Survival in the badlands: An exploration of disaffected students' uses of space in a UK secondary school. British Journal of Sociology of Education, 40(8), 1188-1203.

Rosén Rasmussen, L. (2012). Touching materiality: Presenting the past of everyday school life. Memory Studies, 5(2), 114-130.

Rybczynski, W. (1987). Home: A short History of an Idea. London: Penguin.

Singer, J., \& Woolner, P. (2014). Exchanging Ideas for the Ever-Changing School. In P. Woolner (Ed.), School Design Together. Routledge

Starkey, L., Leggett, V., Anslow, C., \& Ackley, A. (2020). The use of furniture in a student-centred primary school learning environment. New Zealand Journal of Educational Studies (this issue)

Uline, C., \& Roberts, L. (2009). Measuring school facility conditions: An illustration of the importance of purpose. Journal of Educational Administration, 47(3), 368-380. https://doi.org/10.1108/09578 230910955791.

Upitis, R. (2004). School architecture and complexity. Complicity: An International Journal of Complexity and Education, 1(1), 19-38.

Wall, G. (2016). The impact of physical design on student outcomes. Wellington: New Zealand Ministry of Education.

Wood, A. (2019). Built policy: School-building and architecture as policy instrument. Journal of Education Policy. https://doi.org/10.1080/02680939.2019.1578901.

Wright, N. (2018). Becoming an innovative learning environment: The making of a New Zealand secondary school. Cambridge: Springer.

Wright, N., \& McNae, R. (2019). An Architecture of Ownership: Students and teachers forging agentic identities in an innovative learning environment. Final Summary Report. TLRI. Retrieved from http://tlri.org.nz/tlri-research/research-completed/school-sector/architecture-ownership-studentsand-teachers-forging.

Publisher's Note Springer Nature remains neutral with regard to jurisdictional claims in published maps and institutional affiliations. 